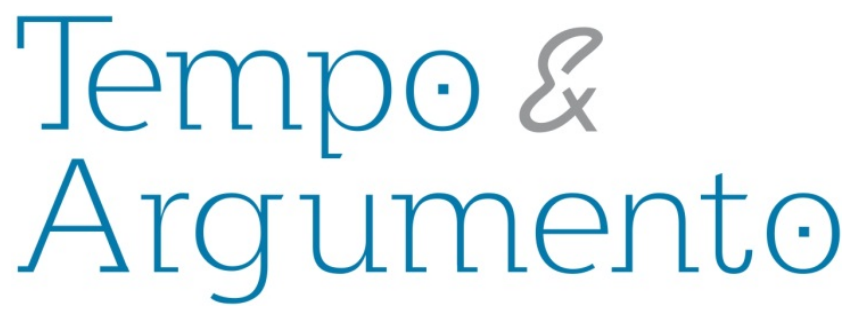

\title{
Intolerance South of America: comparative study of fascist groups from Brazil and Argentina on the Internet (1996-2007)
}

\begin{abstract}
This article investigates the uses of the Internet made by fascist groups from Brazil and Argentina. We use as main sources professedly fascist websites created shortly after the popularization of the Internet. From the perspective offered by the comparative methodology advocated by Marc Bloch, the text examines the relation between Brazilian homepages and the best known South American far-right website, Ciudad Libertad Opinión, created in 1999 with the primary purpose of spreading fascist ideas and providing support to other extremist groups. We point out the strategic role played by the web portal Libre Opinión as articulator between fascist groups in South America, this is a key contributor in the diffusion of Brazilian web pages marked to convey on a regular basis xenophobic, racist, anti-Semitic, and homophobic messages.
\end{abstract}

Keywords: Fascism - Brazil; Fascism - Argentina; Internet;

South America

\author{
Dilton Cândido Santos Maynard \\ Universidade Federal de Sergipe - UFS. \\ Brasil \\ dilton@getempo.org
}

\section{To cite this translation:}

MAYNARD, Dilton Cândido Santos. Intolerance South of America: comparative study of fascist groups from Brazil and Argentina on the Internet (1996-2007). Revista Tempo e Argumento, Florianópolis, v. 6, n.12, p. 276 - 307, mai./ago. 2014. Original title: Intolerância ao Sul da América: estudo comparado de grupos fascistas do Brasil e da Argentina na Internet (1996-2007).

DOI: $10.5965 / 2175180306122014276$

http://dx.doi.org/10.5965/2175180306122014276 
Intolerância ao Sul da

América: estudo comparado

de grupos fascistas do Brasil e da Argentina na Internet (1996-2007)

\section{Resumo}

Este artigo investiga os usos da internet realizados por grupos de fascistas do Brasil e da Argentina. Utilizamos como principais fontes sites declaradamente fascistas criados pouco depois da popularização da internet. Através da perspectiva oferecida pela metodologia comparativa defendida por Marc Bloch, o texto analisa a relação entre as homepages brasileiras e o mais conhecido site sulamericano de extrema direita, Ciudad Libertad Opinión, criado em 1999, com a principal finalidade de disseminar ideias fascistas e prestar apoio a outros grupos extremistas. Apontamos o papel estratégico que o portal Libre Opinión cumpriu como articulador entre os grupos fascistas da América do Sul, sendo um colaborador fundamental na difusão de páginas brasileiras marcadas por veicularem regularmente mensagens xenófobas, racistas, antissemitas e homofóbicas.

Palavras-chave: Fascismo - Brasil; Fascismo Argentina; Internet; América do sul.

\section{The network, the youth, the world}

“- Start through the youth [...] We, those who are older, are fatigued. [...] But my wonderful youth! Are there better ones in the world?", once observed Adolf Hitler (18891945). The concern of the Nationalsozialistische Deutsche Arbeiterpartei, the Nazi party, to raise supporters among young people inspired diligence on the strategies of co-optation of children and adolescents. In Germany, according to Susan Bartolleti, "the Nazis knew what kids liked - uniforms, flags, music bands, badges, weapons, and hero stories - and 
Indeed, combining appeal to tradition - represented by badges, pennants, initiation rituals, chants, etc. - with praise to technology cemented the fascist propaganda since the $1920 \mathrm{~s}^{2}$. Although seemingly contradictory, this proposal finds support in the fact that, on the one hand, fascism "at the same time that violently criticizes the present time and constructs a regressive utopia aimed at the past", on the other hand, "it does not hesitate to resort to using the most advanced means, from the technological point of view, to spread hatred or enforce its dominance over society"3.

In the $21^{\text {st }}$ century, the emergence of the so-called "hate speech" in cyberspace provided the possibility of bringing extremists closer, allowing them greater connection ${ }^{4}$. Despite the difficulty to classify the immense variety of current groups, we may follow the concept of "neo-fascist" or far-right activists, considering the following traits identifiable in all of them: 1. rhetoric of racial and national unity and common destiny; 2. firm belief in a threatened status quo; 3 ideas of racial supremacy; 4. worldview of revolutionary utopia that seeks to overthrow the established order; 4 antiliberalism; 5 anticommunism; 6 . hatred of the convenient other, which may be Jewish at the universal level, but it has variations at local spheres (Northeastern Brazilian people, homosexual men, Muslims, Latinos).

\footnotetext{
${ }^{1}$ BARTOLETTI, Susan Campbell. Juventude hitlerista: a história dos meninos e meninas nazistas e a dos que resistiram. Trans. Beatriz Horta. Rio de Janeiro: Relume Dumará, 2006. p. 14 and p. 31.

${ }^{2}$ Robert Paxton reminds us of things such as rural nostalgia fueled by the fascist propaganda, among which the bare-chested Duce in the midst of harvest is perhaps the best example, contrasting with the cult of the machine: "The leaders loved their cars, fast planes, and diffused their message using extremely modern propaganda and scenography techniques". PAXTON, Robert. A anatomia do fascismo. Trans. Patrícia Zimbres and Paula Zimbres. Rio de Janeiro: Paz \& Terra, 2007. p. 30.

${ }^{3}$ SILVA, Francisco Carlos Teixeira da. O debate do Holocausto como paradigma da intolerância. In: Revista Eletrônica Carta Maior. Available at: <www.cartamaior.com.br>. Accessed on: Mar. 28, 2008; also available <http://www.tempopresente.org/index.php?option=com content\&task=view\&id=1467\&ltemid=124>. Accessed on: Mar. 28, 2008.

4 BACK, L; KEITH, M; SOLOMOS, John. Racism on the Internet: mapping neofascist subcultures in cyberspace. BJØRGO, T.;KAPLAN, J. (Orgs.). Nation and race: the developing Euro-American racista subculture. Austin, TX: Northeastern University Press, 1998. p. 73.
} 
The composition of this "family of resemblances" 5 - that incorporates the primary aspects pointed out by Franz Neumann to describe the Nazi State, such as Behemoth, and Ernest Nolte and his notion of a "fascist minimum" -, wrapped in anticommunism, antiliberalism, antirationalism, and anticonservatism does not disregard the diversity of far-right cultures, but also involves an effort to analyze possible variations of racism, antiSemitism, homophobia, and other manifestations of hatred to the other by using the new technologies ${ }^{6}$.

To understand this phenomenon, some initial questions guide this text: 1 . How have the virtual media been used among far-right activists? 2. Are there specificities when we look at Brazil and Argentina, the two most influential South American nations? 3. Was there some kind of preferred material for dissemination through the network? 4. Has the emergence of the Internet and the social networks contributed to the creation of a global view or has it enhanced localism? 5. Is it possible to identify connections between the groups under study?

Whereas technology has no particular ideology, our proposal is to conduct a political analysis of far-right activism, taking into account the ways how its ideas are conveyed. Thus, we are highlighting and comparing cultural modalities in the fascist practice. In Brazil, among the promoters of hatred and racial supremacy on the web, it is worth mentioning Valhalla. Created in 1997 and removed from service in 2007, by means of a lawsuit and partnership between the Brazilian and the Argentine police, this site has been formerly hosted by the Argentine provider Ciudad Libertad de Opinión (www.libreopinion.com) - perhaps the biggest South American host of far-right web pages. On Valhalla it was possible to find texts by well-known revisionists such as Robert Faurisson and Bruce Hagen.

\footnotetext{
${ }^{5}$ For a discussion on fascism types, see: SILVA, Francisco Carlos Teixeira da; VIANA, Alexander Martins. Dicionário crítico do pensamento da direita: ideias, instituições e personagens. Rio de Janeiro: FAPERJ/Mauad, 2000; NEUMANN, Franz. Behemoth: the structure and practice of national socialism, 1933-1944. Chicago: Ivan R. Dee/United States Memorial Museum, 2009; KERSHAW, Ian. Hitler, the Germans, and the final Solution. London/Yale University Press, 2008; PAXTON, Robert. A anatomia do fascismo. Trans. Patrícia Zimbres and Paula Zimbres. Rio de Janeiro: Paz \& Terra, 2007.

6 BACK, L.; KEITH, M.; SOLOMOS, John. Racism on the Internet: mapping neofascist subcultures in cyberspace. BJØRGO, T., KAPLAN, J. (Orgs.). Nation and race: the developing Euro-American racista subculture. Austin, TX: Northeastern University Press, 1998. p. 76.
} 
Since the first cybernetic manifestations, still in the late 1990s, the ideas of these groups were spread by means of simplification strategies (through slogans, for instance), the construction of a single enemy, the convenient other which, as noticed by Robert Paxton, comprises a variable that can be black people, Northeastern Brazilian people, homosexual men, and often Jewish people? ${ }^{7}$. Therefore, between 1999 and 2007, South American far-right groups, from different matrices, demonstrated the potential of the world wide web.

\section{Digital history: research in times of internet}

The opening of the web to the world, its occupation by non-specialists, allowed by the world wide web, establishes a new era. In it, as claimed by Manuel Castells, economies, cultural activities, government policies, business ventures, health policies and procedures are designed by means of its insertion on the web ${ }^{8}$. Hence the importance of thinking through the future of the art of preserving the past. We have been experiencing an amazing transformation. Amid the avalanche of records, there is the inevitable question: what should we preserve?

Until recently, there were great difficulties to publish an article, make it known and accessible, to publish a book or make contact with sources. As noticed by Roy Rosenzweig ${ }^{9}$, the Internet has significantly changed this context. Instead of a culture of scarcity, a historian must learn to deal with the culture of abundance.

For this essay, a major locus of research was the web page http://www.internetarchive.org. There, by means of the electronic tool www.waybackmachine.org, we could access numerous web pages of groups selected for the analysis, which, after complaints and lawsuits, were removed from service. In this huge virtual "file", many web pages were not complete, and it was usual to find links not

\footnotetext{
7 PAXTON, Robert. A anatomia do fascismo. Trans. Patrícia Zimbres and Paula Zimbres. Rio de Janeiro: Paz \& Terra, 2007.

${ }^{8}$ CASTELLS, Manuel. A Galáxia Internet: reflexões sobre a Internet, os negócios e a sociedade. Trans. Maria Luiza X. Borges. Rio de Janeiro: Jorge Zahar, 2003. p. 11.

${ }^{9}$ ROSENZWEIG, Roy. Scarcity or Abundance? Preserving the past. In: Clio Wired: the future on the past in the digital age. New York: Columbia University Press, 2011. p. 3-27.
} 
In this regard, our experience is similar to that of researchers who are interested in newspapers from the $18^{\text {th }}$ or $19^{\text {th }}$ century. None of these difficulties should ground historian's detachment or occasional attempts to disqualify his/her work when dealing with websites. What is needed, in this case, is complying with the procedures of historical criticism. Criticism should not differ from those adopted by classical historical analysis ${ }^{10}$. As reminded by Antoine Prost, "this is the same method applied to another documentation that sometimes uses specific knowledge" ${ }^{\prime 11}$.

From cyberspace, we must not only identify what is represented, but also take into account the behavior and possible "manufacturing" of users of the world wide web, and think through the key social practices going on there ${ }^{12}$. However, we must immediately dismantle the fragile illusion of dominating this new locus of production and distribution of sources. We deal with an object whose mutation capacity is perhaps unprecedented. And, for this very reason, we must take into account that the study will not be able to encompass all available information sources, because, as claimed by Manuel Castells, the network said "develops and changes much more quickly than the subject", i.e. the researcher ${ }^{13}$.

When facing some documentation that seems to reveal everything and is, at the same time, elusive, "fluid", it will be strategic to observe the revealing detail ${ }^{14}$. The search will look for "privileged areas", "signs", clues that contribute to reflection. In the global web of computers, we should learn to trace "evidence" with which it is possible to think of the past. It is expected, thus, to aprehend not only the projects proposed by the

\footnotetext{
${ }^{10}$ BLOCH, Marc. Apologia da História ou O Ofício do Historiador. Rio de Janeiro: Jorge Zahar, 2001.

${ }^{11}$ PROST, Antoine. Doze lições sobre história. Trans. Guilherme João de Freitas Teixeira. Belo Horizonte: Autêntica, 2009. p. 64.

${ }^{12}$ CERTEAU, Michel de. A Invenção do cotidiano: artes do fazer. Trans. Ephraim Ferreira Alves. Petrópolis, RJ: Vozes, 1994. p. 34.

${ }^{13}$ CASTELLS, Manuel. A Galáxia Internet: reflexões sobre a Internet, os negócios e a sociedade. Trans. Maria Luiza X. Borges. Rio de Janeiro: Jorge Zahar, 2003. p. 11.

${ }^{14}$ BAUMAN, Zygmunt. Globalização: as consequências humanas. Trans. Marcus Penchel. Rio de Janeiro: Jorge Zahar, 1999.
} 
content of websites, but especially its uses, appropriations, and the consumption ways employed by its users ${ }^{15}$. Thus, by seeking to reconstruct the forms of action, change, and representations constructed in the past from an environment such as the Internet, we can expand the debates on the insertion of the digital world in our lives, in our history.

\section{On comparative history}

Regarding the methodological approach, we resort to Comparative History. In History, what means compare? In an article regarded as one of the founding texts of this type of approach, Marc Bloch wrote that comparing is:

[...] faire des choix, dans un ou plusieurs milieux sociaux différents, de deux ou plusieurs phénomènes qui paraissent, au premier coup d'œil, présenter entre eux certaines analogies, décrire les courbes de leurs évolutions, constater les ressemblances et les différences et, dans la mesure du possible, expliquer les unes et les autres ${ }^{16}$.

The author was among the best known advocates of comparatism, perhaps its greatest disseminator. By facing the dark unfolding of nationalisms from the $19^{\text {th }}$ century, when ended up fighting in World War I, he identified in comparatism the ideal method to avoid localism and, thus, escape the dialogue among "deaf" researchers addressing the national phenomena that bothered him a lot.

In his text, Pour une Histoire Comparée des sociétés européennes (For a Comparative History of the European societies), the author advocates for the viability of the comparative method by arguing: “Ce qu'il demande à une méthode, c'est d'être un instrument technique, d'usage courant, maniable et susceptible de résultats positi"17. The comparative method meets these requirements. The author distinguishes two primary types of comparison:

${ }^{15}$ GINZBURG, Carlo. Sinais: raízes de um paradigma indiciário. In: Mitos, emblemas e sinais: morfologia e história. Trans. Frederico Carotti. 2. ed. São Paulo: Companhia das Letras, 1989. p. 143-180.

${ }^{16}$ Our free translation: "Making choices, in one or more different social environments, between two or more phenomena that seen, at first glance, to have some analogies, describing the curves of their evolution, finding out their similarities and differences and, as far as possible, explaining each of them". BLOCH, Marc. Por une Histoire Comparée des societies européennes. In: Revue de Synthèse Historique. 46:15-50. p. 17.

${ }^{17}$ Our free translation: "What we ask of a method is that it is a technical instrument, in common use, handy, and capable of achieving positive results". Ibid., 46:15-50. p. 16. 
1) that showing the similarity between the facts observed - people choose societies detached in time and space from such distances that the analogies, observed in one and another part, between a phenomenon and another one, cannot be explained, of course, nor by mutual influence or community of origin;

2) studying societies sometimes neighboring and contemporary, constantly influenced by each other, undergoing, in its unfolding, precisely due to their closeness and their synchronism, the action of the same great causes, derived from, at least partially, a common origin ${ }^{18}$.

The author of The Thaumaturge Kings - an essay in comparative history about the monarchies of France and England ${ }^{19}$ - defines his preference for the second model. According to Bloch, the second comparative method - which observes close and synchronic societies - is the most limited regarding its skyline, but it is also the richest from a scientific perspective ${ }^{20}$. Such methodological framework proves to be suitable to the research presented in this text.

However, if comparison implies a procedure of selection, abstraction, it also requires decontextualization. Not to get rid of analysis, but to denaturalize it, to deepen it. Thus, comparative approaches only emphasize and probably help expressing what is implicit in all kinds of historical work: a strong selective and constructive component, as pointed out by Kocka ${ }^{21}$.

It is the unit of an issue that should draw the historian's attention, not only the limitations imposed by geography. When dividing a given society to study, we must take into account its "historical integrity", so that it is possible to perform the double movement of seeking for the whole without falling into generalizations. The search for

\footnotetext{
${ }^{18}$ Ibid., 46, p. 17-19.

${ }^{19}$ Id. Reis Taumaturgos - o caráter sobrenatural do poder régio: França e Inglaterra. Pref. Jacques Le Goff. Trans. Júlia Mainard. São Paulo: Cia. das Letras, 2. repr., 1999.

${ }^{20} \mathrm{BLOCH}$, Marc. Por une Histoire Comparée des societies européennes. Revue de Synthèse Historique. p. 19.

${ }^{21}$ KOCKA, Jürgen. Comparison and beyond. History and Theory, Vol. 42, No. 1 (Feb., 2003), p. 44.
} 
Therefore, the product of this method must collaborate to mutual enlightenment, an approach that aims to be supportive. The juxtaposition of interpretations and data should be avoided at all cost ${ }^{23}$. Considering the wealth of observation, from a comparative perspective, on Brazil and Argentina, we believe that this constitutes a fruitful method.

\section{Cyberspace: political arena of the $21^{\text {st }}$ century}

The far-right activists have gained prominence, first, due to their pioneering use of cyberspace. Realizing the economy and agility of networks, they put their hands on the keyboards soon. Still in the early years of commercial Internet, in 1996, the "Times" reported on the web pages of hatred on the rise: "Racists have discovered that the Net is a marvelous way to get their message out to a huge audience at low cost" ${ }^{24}$. With the occupation of cyberspace, it was possible to avoid the often dangerous face-to-face contact. In the electronic age, the ability of domestic groups in countries such as the USA to constitute international partnerships has been significantly expanded with the assistance of computers, as well as with tools such as the fax and resources such as desktop publishing.

The simple idea that anyone can express her/his worldview to an immense mass has significantly contributed to the development of online extremism. Exploring the potential of the Internet, disseminators of racial hatred ideas enhanced their ability to act in the real world. Unlike other times, pamphlets are no longer mimeographed or photocopied. Now, they are sophisticated and very visually-appealing homepages. The

\footnotetext{
22 PRADO, Maria Ligia Coelho. Repensando a história comparada da América Latina. Revista de História. Universidade de São Paulo, n. 153, 2005, p. 11-33.

DA AMÉRICA LATINA. Revista de História, n. 153 (2 - 2005), 11-33, p. 22.

${ }^{23}$ BARROS, José D'Assunção. História Comparada - um novo modo de ver e fazer história. Revista de História Comparada. Junho 2007, v. 1, n. 1, p. 23.

24 QUITTNER, Joshua, STAMPER, Chris. Home pages for hate. Time. Jan. 22, 1996. Available at: <www.time.com/time/.../0,9171,983994,00.html>. Accessed on: Aug. 20, 2011.
} 
military marches of the SS (Schutzstaffel), the Nazi elite troop, after sampled, gave rise to “techno Nazi” songs such as "Adolf Hitler Party (Swastika Mix)", by DJ Adolf. One of these songs parodies "The Battle Hymn of the Republic", a civic-religious hymn created in 1861, popularized in the Civil War of the United States (1861-1865) ${ }^{25}$. On the Internet, it became possible to buy disks of bands such as Racist Rednecks Rebels, or simply download on MP3 angry songs such as those by the Brazilian band Brigada $\mathrm{NS}^{26}$ or by Rahowa, whose track "Third Reich" says "You kill all the niggers and you gas all the jews/Kill a gypsie and a commie too"27.

\section{1 intolerance.com.ar}

Accompanying this movement, on September 21, 1999, during the very process of explosion of the Internet, there came the Argentine web portal "Ciudad Libertad de Opinión" (http://www.libreopinion.com), owner of the IP 190.228.30.234, registered in Buenos Aires. Soon, this web page became the best known South American far-right website, hosting Bolivian, Chilean, Ecuadorian, Peruvian, Brazilian, Argentine, and Venezuelan groups. Some Brazilian White Power Skinheads wrote, in English, on this web

25 "My eyes have seen the glory of the trampling at the zoo,/We washed ourselves in niggers blood and all/ the mongrels too,/We're taking down the Zog machine jew by jew by jew,/The white man marches on". DJ Adolf. The white man marches on. Available at: <http://www.autolyrics.com/lyrics/for/The_White_Man_Marches_On/by/American_History_X>. Accessed on: Mar. 20, 2008.

${ }^{26}$ Here are some professedly fascist bands devoted to "White Metal" - a subgenre of Heavy Metal music around the world: in Brazil - Command, Corrosão, Defesa Armada, Goat Penis, Grupo Separatista Branco, Locomotiva 88, Resistência 88, and Thallium; in Argentina - Accion Radical, Comando Suicida, Nuremberg, Razon y Fuerza, and Ultrasur; in Chile - Odal Sieg; in Portugal - Guarda de Ferro and Lusitanoi; in Spain - British Standard and Nemesis; in Italy - SPQR and Intolleranza; in Hungary - Junkers 88; in England - White Law, Avalon, and Blackshirts; in France - Kontingent 88 Kristallnacht and Legion 88; in Russia - Totenkopf and Terror National Front; in Poland - Falanga 88, Swastyka, and Zyklon B; and in Germany - Reichssturm, Eugenik, and War 88. White Power Music Groups. Available at: <http://www.adl.org/learn/Ext_US/music_country.asp>. Accessed on: Mar. 152008.

${ }^{27}$ Rahowa is the greeting of believers of the World Church of the Creator, derived from the Church of the Creator, created by Ben Klassen, a U.S. citizen from Florida, son of German immigrants, who committed suicide in 1993. The sect was remodeled by reverend Matt Halle, from Illinois, USA. The greeting is the acronym of the expression "Racial Holy War", which advocates for the elimination of "natural enemies" - blacks, mestizos, Jews, communists, homosexuals. The WCOTC has gained ground thanks to the use of the Internet. Reverend Halle has invested in cyberspace and got significant fruits. He said: "The internet has the potential to attract millions of white people with our message and we need to use it without delay". Cf. NEONAZISMO web (I): Radiografia do templo do ódio. Available at: <http://www.abknet.de/wcotc.htm>. Accessed on: Oct. 222005. 
However, by means of action taken by the Brazilian Justice and partnership between the federal police of both countries, in 2007 the Argentine portal was forced to delete the websites produced by Brazilians. Among the websites disabled, we can identify, for instance, web pages such as Valhalla 88, White Power SP, Blood and Honour Southland, and White Honour. Nevertheless, by removing these websites from service, the authorities have obtained only a partial victory. The ideas of hatred and intolerance have not lost ground, above all considering the fact that the same groups had already moved on to further spread their actions, exploring hosts outside South America, and, in most cases, migrating to the social networks, which emerged since 2003.

These cases show that, in the late $20^{\text {th }}$ century, a virtual network of far-right groups was assembled through the Internet. Between 1999 and 2007, most of the South American web pages like this was hosted by Ciudad Libertad de Opinión. The Argentine site worked as a web portal, aggregating various kinds of homepages, providing links, activity options, solutions to violent and clandestine operations, articulating a proposal of joint action and dispersed action, at the same time.

\subsubsection{The Argentine Nazis go to the network}

Ciudad Libertad de Opinión was created by the Argentine activist Alejandro Carlos Biondini, leader of Partido Nuevo Triunfo (PNT), former Partido dos Trabalhadores, a political byproduct of the Peronist far-right ${ }^{28}$. Biondini's option for the Internet was strategic. His party, officially established in 1990, did not gain the desired space, and its proposals, clearly inspired by German fascism, had led it to face lawsuits in court. Therefore, the migration to the world wide web may be explained by the idea that being

\footnotetext{
${ }^{28}$ KOLLMANN, Raúl. Sombras de Hitler: la vida secreta de las bandas neonazis argentinas. Sudamericana: Buenos Aires, 2001. p. 101.
} 
Since the late 1990s, the web page was the main articulator of several South American extremist groups. By means of the web portal, for instance, it was possible to reach the Brazilian website of Combat 18, a well-known neo-Nazi group. There, the forums gathered curious people, mostly ardent supporters of intolerance. Thus, motivating and trying to coordinate actions taken by groups in various parts of the world, the website Ciudad Libertad de Opinión acted freely between 1999 and 2007, when it started facing lawsuits filed by governments, such as the Brazilian, which managed to identify some of those responsible for the web pages hosted there and claimed that they should be punished. Although before the popularization of the Internet extremist far-right groups already showed strength through actions taken in Brazil and Argentina, the installation of organizations overtly inspired by fascist ideas in cyberspace marks a new initiative, which still lacks reflection.

\subsubsection{The little Führer}

Who is Alejandro Biondini? Son of a communist leader and a Catholic mother, professedly anti-Semite, Alejandro Carlos Biondini was born on January 12, 1956, in Buenos Aires. According to information provided by him, he prepared himself to lead Argentina from an early age. He served in the Peronist Youth, volunteered in the Falklands in 1982, and founded, in 1983, Alerta Nacional, embryo of the future Partido Nacionalsocialista de los Trabajadores, created in May 1990, from an orthodox Nazi perspective; i.e. the organization proposed to be an emulator of the original Nazi group created in Germany in the 1920 .

Prohibited from using the name "nacional-socialista", Biondini renamed the group as Partido Nuevo Triunfo (PNT). After some attempts to hold marches, still in 1990, the politician was arrested due to Nazi propaganda, when he attached the swastika to the building of the Argentine Congress and to some areas downtown in Buenos Aires. By 
breaking the Law $23.592^{29}$, the activist, ironically nicknamed by the country press as "the little Führer", remained in jail for 200 days.

Making a point of having his name attached to Peron, Franco, and the fight against England in the Falklands, Biondini inspires a certain mystery regarding his pathway. A doubt concerns his supposed predestination as a leader of Nazi resurgence. As he suggests, Hitler himself, in the eclipse of the Third Reich, looking at the map of the world, had allegedly pointed at Argentina stating that his true successor would come from there ${ }^{30}$. The Argentine politician was wrapped, on purpose, in a mystery aura and he leaves easy clues to followers, such as his enrollment number in PNT - number 7 -, as well as that of his German idol. It is also like this in initiation ceremonies, which take place on August 7, Saint Cajetan's day, 7:07 p.m., when 7 new “initiated” are incorporated into the group $^{31}$.

"Saint Cajetan's cross", used as one of its official symbols, is interpreted as representing the "Crislam", since it incorporates the Catholic cross and the Islamic crescent moon. In short, it might be an icon of the alliance between Christians and Muslims against Judaism. Moreover, Biondini uses the same resource to provide a mystical definition, "Kalki", through which he is called by followers and among websurfers. Kalki is the $10^{\text {th }}$ and final incarnation of Vishnu who, according to Hindu mythology, will lead the era of darkness to an end ${ }^{32}$. In addition to an evocation of the leader as a god, PNT initially had the same slogan of its Germanic inspirer: "Un Pueblo, una

${ }^{29}$ According to the Argentine legislation, Biondini broke, at least, Law 23.592, Article 3, which states, according to our free translation: "Those who participate in an organization or undertake propaganda based on ideas or theories of the superiority of a race or group of people with a certain religion, ethnicity or color, aimed or intended to promote racial or religious discrimination in any form, will be punished with imprisonment from 1 month to 3 years. The same penalty will incur on those who, by any means fosters or incite persecution or hatred against any person or group of persons because of their race, religion, nationality, or political beliefs". Available at: <http://www.apadeshi.org.ar/leyantidicriminacion.htm>. Accessed on: Nov. 20, 2012.

${ }^{30}$ KOLLMANN, Raúl. Sombras de Hitler: la vida secreta de las bandas neonazis argentinas. Buenos Aires: Sudamericana, 2001. p. 23.

${ }^{31}$ Ibid., p. 21.

32 Ibid., p. 22. 
In 2004, Partido Nuevo Triunfo had its application for registration as a party able to participate in Argentine elections denied. Biondini has even softened his discourse included in the organization's program submitted to assessment by the Electoral Justice. However, even the 4,000 signatures gathered (although their validity has been strongly contested) were not enough to regularize PNT. Various institutions were against the legalization of the Argentine Nazis, such as Secretaría de Derechos Humanos, at the time headed by Eduardo Luis Duhalde, and Instituto Nacional contra la Discriminación (INADI), which has stated in litigation that:

Exaltan la violencia, exhortan al odio contra quienes son miembros de la comunidad judía nacional e internacional, como así también reivindican al líder nazi Adolfo Hitler, las insignias del partido Nacional Socialista Alemán, todo ello en franca contradicción con los valores democráticos ${ }^{34}$.

The results of notes such as those by INADI motivated the negative court decision, thus preventing the party to gain ground for its xenophobic discourse that, although loosely disguised in the printed text submitted for purposes of regularization, was kept in its entirety on the Internet ${ }^{35}$. At the same time they submitted a printed document claiming that the group was opposed to "all kinds of racism and antisemitism" and putting aside the use of the swastika (according to the minute $8 / 2003$ by the party), Biondini and followers continued to bluster, on the web page Libre Opinión, their fascist rhetoric. PNT's page, which continued accusing the existence of a "homosexual

33 Our free translation, both from Spanish and German: "One nation, one people, one leader". Cf. KOLMANN, Raúl. Los neonazis usan maquilaje. Página 12. Dec. 24, 2003. Accessed on: July 20, 2012. Available at: <http://www.pagina12.com.ar/imprimir/diario/elpais/1-29682-2003-12-24.html>. See also: KOLMANN, Raúl. Un parate legal para el partido del pequeño führer. Página 12. Oct. 20, 2003. Available at:

<http://www.pagina12.com.ar/imprimir/diario/elpais/1-27043-2003-10-20.html>. Accessed on: July $20,2012$.

${ }^{34}$ Our free translation: "They praise violence, exhort hatred of those who are members of the national and international Jewish community, as well as claim to the Nazi leader Adolf Hitler the badges of the German National Socialist Party, everything in clear contradiction to the democratic values". KOLMANN, Raúl. A loz nazis les dicen “nein". Página 12. Feb. 7, 2004. Available at: <http://www.pagina12.com.ar/imprimir/diario/elpais/1-31220-2004-02-07.html>. Accessed on: July 20, 2012.

35 See KOLMANN, Raúl. LA JUSTICIA NO ACEPTO LEGALIZAR AL PARTIDO NAZI. Página 12. 10 mai. 2004. In: Argentina: un giudice nega la legalizzazione di un partito neonazista. Available at: <http://www.peacelink.it/latina/a/4881.html>. Accessed on: Sep. 12, 2012. 
PNT had another registration request denied by Cámara Nacional Electoral and the Supreme Court of Argentina, which, according to the Clarín of March 17, 2009, stated: "No se pueda legitimar como partido político a quienes incurren en apología del odio e, indirectamente, incitan a la violencia" 37 . In the end of the $20^{\text {th }}$ century, the migration of its operations for the world wide network of computers was the alternative found to try gathering more fans. Since the new failure to obtain the legalization of PNT, Biondini/Kalki aimed his efforts to expand Portal Ciudad Libertad de Opinión, as a sort of virtual version of the party. Through the website, the netkrieg (a network war inspired by the model of coordinated blitzkrieg) began. Boasting to be guided by the ethical principles "God, Country, Social Justice, and Family", Libre Opinión started offering Internet users, since their first moments on the network, a wide range of navigation options: forums, online games, information about Argentina and neighboring countries through Agencia de Noticias RED KALKI or Tablero de Anuncios.

\subsubsection{The Pantheon}

Among the news, there are manipulations such as those related to the deaths of “martyrs" of the party - Luis Alberto Vera, Alfredo Guereño, and René Túlian. The first was reportedly killed in a Jewish ritual, in which his blood was fully removed and, then, his body was thrown into the hoistway from the $9^{\text {th }}$ floor; Vera was reportedly shot to death $^{38}$ without any explanation; Túlian, runned over, arrived conscious at the hospital, but he was reportedly poisoned by a Jewish physician linked to Delegación de Asociaciones Israelitas Argentinas (DAIA), Delegation of Israeli Argentine Associations) ${ }^{39}$. However,

\footnotetext{
${ }^{36}$ KOLMANN, Raúl. Los neonazis usan maquilaje. Página 12. Dec. 24, 2003. Accessed on: July 20, 2012. Available at: <http://www.pagina12.com.ar/imprimir/diario/elpais/1-29682-2003-12-24.html>.

${ }^{37}$ Our free translation: "It is not possible to legitimize as a political party those who engage in hate speech and, indirectly, incite violence". La Corte Suprema le negó la personería jurídica a un partido nazi. Available at: <http://edant.clarin.com/diario/2009/03/17/um/m-01879057.htm>.

38 See: http://web-beta.archive.org/web/20040615155657/http://pnt.libreopinion.com/vera.htm. Accessed on: Dec. 202011.

39 Id. ibid.
} 
For instance, the death of René Túlian, vice president of PNT, which was given a fantastic narrative, does not find support in the medical records, which show the exaggeration and the appropriation of the accidental death of this activist. According to Raúl Kollmann, Túlian actually died at Hospital Argerich, but several hours after his admission, and not within minutes, as stated by the "electronic pantheon" of PNT. "No lo atendió un médico judio, sino la doctora Lucrecia Valdez. El acidentado tenía politraumatismo, traumatismo craneoencefálico grave y fractura leve del occupital. Ingresó en coma y sin reflejos" ${ }^{40}$. Due to his condition at the time of admission, he may have received some medication, however, the autopsy did not detect any toxic substance.

Apparently, the stab-in-the-back myth, fostered by Biondini, was repeatedly used by Libre Opinión. The attempt to form a sort of "Pantheon" of fallen heroes signals this. However, considering the existence of more than two decades of the group, which emerged still in the 1980s, its very limited penetration among Argentine voters highlights the failure of attempts to make the movement grow.

Through the website and radio communications, Kalki discloses a xenophobic and anti-Semitic discourse, criticizes the left-wing parties and everything that reminds communism. However, more than the discourse of "little Führer", the action of LO must be analyzed in terms of the ability that the web portal provided small South American groups with in order to establish exchanges. In an era with no free social networks available, in the days of Internet 1.0, when Google was not working as the great oracle of the cyberworld, a web portal designed by Biondini fostered intolerance. Thus, its effects must not be sought only in vectors of success or electoral defeat, but they require reflection on the ramifications, material exchanges made possible by the Argentine website to fascists from various locations, to groups of various sizes.

\footnotetext{
${ }^{40}$ Our free translation: "He was not treated by a Jewish physician, but by Dr. Lucrecia Valdez. The accident victim had multiple trauma, severe head trauma, and mild occupital fracture. He was admitted in coma and without reflexes". KOLLMANN, Raúl. Sombras de Hitler: la vida secreta de las bandas neonazis argentinas. Buenos Aires: Sudamericana, 2001. p. 109.
} 
The actions taken by authorities against the website failed to prevent the proliferation of "hate webpages" in South America. The emergence of the Internet 2.0 provided activism with new tools. The ease for producing weblogs, the lure produced by social networks such as My Space, Orkut, YouTube, Facebook, and, more recently, Twitter has provided extremists with a larger and more sophisticated repertoire.

\section{2 intolerance.br}

\subsubsection{Brazil, the network, and the lone wolves}

The production of "hate web pages" in the Brazilian Internet has received strategic support from its partners worldwide. From the USA, extremists known as Nazi Lauck $^{41}$, offered, from the very first moments of the telematics network operation through "www", the coordinates to use cyberspace to spread the hatred of the other. Moreover, the use of stormfront forums enabled contacts in the early days of the new network. However, probably the greatest support came from Argentina, through the aforementioned web portal Ciudad Libertad de Opinión. By means of this immense telematic environment, a considerable part of the Brazilian neo-Nazis managed to air their first web pages, in order to provide their email addresses with visibility, disclosing

${ }^{41}$ Gary "Gerhard" Lauck - Gary Lauck or Gary "Gerhard" Lauck, a U.S. neo-Nazi activist, has founded the Nazionalsozialistische Deutsche Arbeiterpartei/Auslandsorganisation (NSDAP/AO), the "German Socialist National Workers Party/International Organization". Despite being a small organization, its founder, who appears in photos on the Internet dressed as a Nazi in the 1930s, gained respect in the world National Socialist movement. Lauck reveals all his ardor towards Nazism and detaches from influential American extremist sectors by changing his name from Gary to Gerhard (a Germanic version). He also spoke English with a German accent, and grew a mustache similar to Hitler's. Before becoming a leader in his own movement, Lauck joined the "National Socialist White People's Party" (NSWPP), and, then, the "National Socialist Party of America" (NSPA). In both parties, he reached prominent positions. However, in 1977, NSPA faced scandal and neglect after the discovery that the party chairman, Frank Collin, was son of Max Simon Collin (but his original name was Cohen), a survivor of the Dachau concentration camp for Jews and, besides, a homosexual pedophile, a fact that is evidenced by his arrest in flagrante delicto due to having sex with two 10-year old boys and the subsequent conviction for child molestation. After such a setback, Lauck became totally devoted to the "NSDAP/AO". He specialized in distributing Nazi propaganda throughout the world and has become the most important distributor of the international Nazi movement. The internet, however, dislodged him from the comfortable position, as downloads and file exchanges started taking place in a decentralized way. 
The emergence of the social networks, however - most of them free -, but also the high standard of interfaces and data sharing, combined with the growing number of complaints filed with the authorities of both countries have put the Argentine website in the background for the Brazilian activists.

A significant part of websites exchanged all kinds of material: translated articles, excerpts from speeches by Nazi leaders, scanned posters of the Third Reich, cartoons against minorities, digital fanzines, and lots of music. The sound of intolerance has gained momentum in cyberspace. By the way, in the absence of a leader who could amalgamate a large amount of followers, music (mainly rock and its subgenres) was chosen to contribute to lure new Nazis.

Through the Internet, by using records on $\mathrm{MP}_{3}$, it was possible to share quick lessons of hatred to what was different, against diversity and simplifying reality. This is what we can see in songs such as "Migração", by the Brazilian neo-Nazi band Brigada NS (NS - National-Socialist), included in an album titled "O retorno da velha ordem": "Dia após dia, migram do Nordeste, centenas de imundos/que são uma grande peste" ${ }^{42}$. Thus, the white boys fought listening to the sound of Rock Against Communism (RAC), a subgenre of rock consisting of bands that address significant issues from the far-right point of view, usually resorting to overt praise of fascism and Nazism. Taking an attitude of "complaint" against Marxism, RAC emerged in the early 1980s, mainly represented by bands such as Skrewdriver ${ }^{43}$. Thanks to the potential to attract young people to the

\footnotetext{
${ }^{42}$ Our free translation: "Day after day, they migrate from the Northeast, hundreds of dirty people/who are a great plague". BRIGADA NS. O retorno da velha ordem. [São Paulo, Spain]: Divisão 18, 1998.

${ }^{43}$ Skrewdriver, variation of the word Screwdriver, this band was one of the most prominent from the genre British White Power. Founded by Englishman lan Stuart Donaldson, its songs have strongly nationalistic, xenophobic, racist, anti-Semitic, and anti-democratic lyrics and they became anthems for the neo-Nazi skinhead youth from various parts of the world. Having a punk origin, after 1978, when lan Stuart was attending the meetings of the National Front, the British far-right party, prejudice, chauvinism, and conservative thought were gradually gaining ground in group compositions, attracting an equally intolerant audience. In the mid-1980s, the band signed a record contract with White Power Music recording companies and it tried to fit its style into Rock Against Comunism (RAC), and it was overtly positioned as neo-Nazi.
} 
Instead of sophisticated manifestos or lengthy and tiresome doctrinal lectures, the fascists of cyberspace tried to provide a charming material, with electronic games, chats, and songs which called for "action" where there was no time to think. Through the web, the repertoire of resources to praise and practice intolerance took previously unimagined dimensions due to its speed, convenience, and mainly its low cost. Thus, while the world wide web was still making fans in Brazil, while the number of computers in the country was far from the standards of developed countries (we had about 5 million in 1998$)^{44}$, the neofascist activists were quickly handling websites, resorting to the digitization process, and meeting the requirements of netkrieg. As Bloch noticed considering the French defeat by the Germans in World War II, speed was the key to explain how it all happened with no possibility to prevent these facts ${ }^{45}$. Nowadays, Nye Jr. reminds us, besides speed, another factor is allied to the network and helps explaining its unique position: low cost ${ }^{46}$.

\subsubsection{A Brazilian Valhalla}

The Brazilian web page Valhalla $88^{47}$ (IP 69.73.138.107) and its contents were easily available between 1997 and 2007. After the action taken by the Federal Police and the cessation of website services, a part of the material therein was provided by the Spanish web portal Nueva Orden, which thus became the main link of one of the most active intolerance websites in South America, a reputation achieved mainly thanks to the support of its original host, the Argentine web portal libreopinion.com. During its decade in operation, its main targets were blacks, Jews, homosexuals, immigrants, and especially Northeastern Brazilian people ${ }^{48}$.

\footnotetext{
${ }^{44}$ For official information on the Internet in Brazil, see: <http://www.cetic.br/>.

${ }^{45}$ BLOCH, Marc. A estranha derrota. Rio de Janeiro: Zahar, 2011. p. 42.

${ }^{46}$ Cf. NYE JR, Joseph. O futuro do poder. São Paulo: Benvirá, 2012.

${ }^{47}$ Available at: <http://www.nuevorden.net/portugues/valhalla88.html>.

${ }^{48}$ MAYNARD, Dilton Cândido Santos. Intolerância em Rede: Apropriações da Internet pela Extrema-Direita (1999-2009). In: Anais Eletrônicos do II Seminário de Pós-Graduação em Ensino de História. Faculdade São
} 
Valhalla 88 has gained fame in the network due to the variety of its material and by the fact of being stable, unlike other websites that quickly disappeared. Thus, this regularity, the "commitment to the cause", drew the websurfers' attention. Added to this, in the era of Internet 1.0, with dialup connection and limited sharing capabilities, the group made images available - photos, flyers, posters of the Third Reich, cartoons, videos, MP3 audio -, but also texts regarding the so-called "historical revisionism" and a large amount of doctrinal material. The creators of Valhalla 88 lived in Santa Catarina, southern Brazil. The website reached the significant figure of 200,000 daily visits, thus becoming one of the most attractive National-Socialist links in South America.

Initially hosted on the web portal Libreopinion.com, Valhalla88.com was tracked by the Federal Police and members of the Jewish Community in Brazil, something which forced it to seek for "hosting" in the USA, but soon after it was removed from service. Brazilian neo-Nazis, mostly skinheads, used to praise on Valhalla 88 the domination of the “Aryan blood" as an element of racial identity ${ }^{49}$.

The first name of the website itself reveals the mystical appeal that it intended to have. The name "Valhalla" derives from Norse mythology, it is a reference to the castle that houses the warriors killed in combat. The number " 88 " corresponds to the $8^{\text {th }}$ letter of the alphabet in sequence ( $\mathrm{HH})$, an acronym for "Heil Hitler" 50 . The group ends up, thus, getting closer to other well-known neo-Nazi groups, such as Alejandro Biondini/Kalki or Miguel Serrano, the Chilean leader of a fascism rather aimed at a mystical ethos. The neo-Nazism practiced by the national websites, emulating examples from Europe and nearby countries, such as Argentina, gathers myths, narratives, and supposedly "heathen" rituals, promoting the superiority of the Aryan race. According to Adriana Dias, "these racists, Nazis, and revisionists construct and update myths, assigning to the word

Luís de França, Aracaju/SE: 2009; Nueva Orden. Available at: <http://www.nuevorden.net/main.html>. Accessed on: Oct. 8, 2008.

49 "Considering only Valhalla 88 , for instance, its more than 1,500 pages might be similar to 17 middle-sized websites, if we take into account all the websites and about 50 websites if we disregard the large web portals. The racist network is, therefore, very significant in size: the websites are reproduced by thousands and the vast majority occupies the space of dozens of them". Cf. DIAS, Adriana Abreu Magalhães. Os Anacronautas do Teutonismo Virtual: uma etnografia do neonazismo na Internet. Campinas, SP: [s. n.], 2007. p. 94-95.

${ }^{50}$ SALAS, Antonio. Diário de Um Skinhead: um infiltrado no movimento neonazista. Trans. Magda Lopes. São Paulo: Planeta, 2006. 
The argument of imminent danger to the race was repeatedly used by Valhalla 88. The aggression, prejudice, xenophobia reigning there were nothing when compared to the unfair treatment and persecution they supposedly suffered on the part of the Zionist Occupation Government (ZOG).

During its period of operation, Valhalla 88 held a widely attended forum, called Livro de Odin, a space where ideas from various skinhead tendencies were manifested. After the banning of Libre Opinión, Valhalla struggled to keep operating. The uprising against the suspension of the support provided by the Argentine website is observed in various releases. This is the case in the announcement by the "southern Nazis", which was supported by Valhalla 88 to keep some information available ${ }^{52}$.

The whole case that has led to the deactivation of the webpages was addressed by those responsible for such electronic environments as "persecution against the cause". In the case of Valhalla 88 and NSS, the "Jewish worms" emerge as the main responsible for all sorts of problems arising from its intolerant activism. This was the perspective through which the Brazilian fascists, just like their Argentine partners, interpreted the unfolding of their activities in cyberspace. The same lens was used to think of the relation between the States of the Federation, forging the fixed idea of workers' exploitation - white Aryans, having a markedly European descent - by social parasites, i.e. immigrants, blacks, Jews, homosexuals, communists, and foreigners as a whole. However, unlike the Argentine, Brazilian activists were more dispersed, without any intent of forming legalized and large groups. The ideology of "lone wolves" seems to have had, herein, a stronger embracement.

\footnotetext{
${ }^{51}$ DIAS, Adriana Abreu Magalhães. Os Anacronautas do Teutonismo Virtual: uma etnografia do neonazismo na Internet. Campinas, SP: [s. n.], 2007. p. 26.

${ }^{52}$ http://www.valhalla88.com/nazistassulinos/mensageiro88.html. Accessed through www.waybackmachine.org on: Dec. 20, 2012.
} 


\section{Brazil and Argentina: far-right movements and cyberspace from a comparative perspective}

In Brazil, the adoption of a cellular structure and the recurrence of the idea of "lone wolf" emerge in a clearer way than that observed in Argentina. This is the way how the "Brazilian National-Socialist Party", whose web page is www.nacional-socialismo.com, created on December 19, 2008, shortly after Valhalla 88 was removed from service, states its position:

The Brazilian National-Socialist Party does not require formal membership. There is no "membership number card". We do not ask any personal information of our collaborators; in fact, we suggest people to take maximum caution with any type of data that could compromise personal safety and the group around her/him. The person should know how to act as a "Lone Wolf". Joining the party involves the commitment of each person to promote the National-Socialist worldview, the individual determination to fight for her/his way of life. This is the actual membership: the commitment to the ideal and self-denial in favor of the collective interest ${ }^{53}$.

Unlike the vast Jewish community living in Argentina - the $5^{\text {th }}$ largest in the world -, with figures exceeding 300,000 inhabitants (within a total population of 40,764,561), in Brazil, whose population now exceeds 193 million, there are just over 100,000 Jews. Despite the similarity in quantitative terms, there are other major targets of the Brazilian far-right, instead of Jews. Playing the role of a crucial factor of the fascist paranoia, the threatening element, the "convenient other", is displaced from the figure of the Jew to the Northeastern Brazilian person, the black person, or the homosexual man. In turn, in the Argentine case, this displacement, always casual, seems to be expressed against Paraguayan, Peruvian, and Bolivian immigrants. They are those regarded as "shabby" poor, sick, leeches on the national resources.

In Argentina, the complex relations between far-right activists and sectors from the various military governments and corporations make understanding the problem even more difficult. The well-known embracement provided by Juan Domingo Perón to

\footnotetext{
53 http://www.pbagora.com.br/conteudo.php?id=20110519160010.
} 
the fugitive Germans ${ }^{54}$ who participated in different positions of the Third Reich, as well as their incorporation into the staff of the Argentine government, their stay even after the fall of Perón, and their subsequent collaboration to the Argentine military dictatorship demonstrate that the fascist practices had followers and that Biondini's claims have found resonance boxes.

In Brazil, if the cases of anti-Semitism have lower incidence, the network has served to disseminate hatred of gays, Afro-descendants, and Northeastern Brazilians on a regular basis. However, the far-right groups mentioned herein should not be regarded as a homogeneous block. The integralists' ideas soon collide with those of neo-Nazis: “At the time when you embrace Brazil or ideologies such as integralism, you are embracing miscegenation, we should care about our race, regardless of borders or countries" 55 . And the shots hit illusive allies and consensual enemies.

The longevity of websites such as www.valhalla88.com suggests much about the difficulties to fight online intolerance. In turn, the ongoing persecution of gay and Northeastern people in the streets of São Paulo and other cities in the country signals the need to think about the problem in-depth. Another aspect to be considered is the weight of regional tensions in the interpretations made by national fascists. After all, most of the websites under study belong to groups located in the Brazilian South and Southeastern regions or in the Argentine federal capital. The plasticity of interpretations seems to be needed so that the skinheads in Porto Alegre forget they are regarded as "sudacas" when compared to their European counterparts or that the so-called bald men in São Paulo and Alagoas relativize skin color in face of white supremacy arguments. The only sense of regularity between these groups seems to be homophobia and sexism.

\section{Final remarks}

While we notice a better organization in Argentina, with attempts to architecture a network and pre-defined hierarchies, in Brazil it does not seem to be so consistent, and

\footnotetext{
${ }^{54}$ Regarding this, see: GOÑI, Uki. The Real Odessa: how Péron brought the nazi war criminals to Argentina. London: Granta Books, 2002.

${ }^{55}$ http://www.valhalla88.com/valhalla.html. Accessed on: Aug. 8, 2006.
} 
the cases of "lone wolves" among the activists constitute the most frequent pattern. However, we noticed in both situations the presence of extremist activities, since the early years of commercial Internet, in the mid-1990s The colonization process of cyberspace by Brazilian and Argentine groups was made possible only when the network became accessible to non-specialist users.

At the end of the last decade of the $20^{\text {th }}$ century, a time expected to be the beginning of a long period of peace and harmony between peoples, historians had their eyes wide shut and intolerance was gaining ground through electronic games, songs, photos, attack plans, historical revisionism, attacks on Jews, immigrants, blacks, homosexuals, and all other "natural enemies" of the white Aryan man. All this was articulated through the use of Internet.

The web pages of hate and their creators in Brazil and Argentina attracted young people, beat opponents, and escaped for years from any punishment. The occupation of cyberspace by far-right groups has taken major steps thanks to neglect and the very novelty of the telematic networks. Politicians, jurists, intellectuals, and various activists were caught by surprise.

It is also worth noticing that, when we consider the digital universe of the two countries, we have to take into account their respective itineraries in economic development and the incorporation of technological changes. In Argentina, the combination of reforms promoted still in the first Menem administration, which changed the panorama of the national economy and made communication cheaper - but, at the same time, deepened social differences and gave rise to landslides in terms of purchasing power and quality of life for a significant portion of the population -, along with the persistence of far-right segments identified with the fascist ideals, enabled the advance of Partido Nuevo Triunfo on the web. However, the limited social penetration of this group was evidenced by defeats in the courts and the poor resonance of marches and events held by it.

However, the context is even more complex. If, on the one hand, we can perceive the electoral failure of extremists such as Alejandro Biondini, the relations that he and his 
PNT failed to enlist thousands of followers as it intended. The few people involved, however, play a similar to that of the Hitler Youth in Germany's Third Reich. They are the so-called mad dogs, the terrifying ones, the detractors of opposition late at night and, often, those responsible for the personal protection of fascists in suits.

By moving most of his operations to the network in 1999, Biondini ended up contributing to the exchange between various and small groups across South America. Of course, Kalki has gained fame in the neo-Nazi underworld. However, what we find out is his intent to achieve electoral success or, if it occurs, play a strategic role in a new military coup d'État.

In Brazil, the convenient other seems more difficult to be identified. Our "Jew" is not one, but many. He is black, homosexual man and woman, Northeastern Brazilian, communist, woman, and also Jewish. Thus, the conservative element is rather a behavioral aspect than exactly a fixed trait of a political ideology. A skinhead can accept an Afro-descendant, just like the Brazil bald men, the bald men from Alagoas, but reject, persecute, and kill homosexual men.

At the same time, the malleable discourse adopted in the Brazilian web pages occurred mainly when the discussion came around the theme racism, while issues related to respect for human rights were accompanied by a marked intolerance. There was a need to justify the existence of "mestizos" in the groups, but no gaps have been identified for gays and all groups were flagrantly sexist.

One of the corollaries of the ongoing adaptations within the fascist ideology adopted by Brazilian groups resulted in difficulties to articulate joint actions and in the failure to adopt a single leadership. If the option for lone wolves suggests, on the one hand, weakness on the part of fascists to rise through legal channels, it shows, on the other hand, the worrying spread of militants who have silent wishes of "revenge" against society. 
By conducting a comparative analysis between Brazil and Argentina, we identified worrying similarities, but also differences that point at the historical specificities of each country. A generalization is not possible, nor interesting. In both cases, we notice the complexity of resurgent fascism and its wider distribution through electronic networks. Just as Bloch asked, we need to adapt to the new and, thus, perhaps, we can better understand this time. Thus, the analysis of fascist behavior in the $21^{\text {st }}$ century emphasizes the need to consolidate the field of Digital History, because within it we can better observe environments such as cyberspace, complying with its specificities.

\section{References}

ARQUILLA, John and David Ronfeldt. Conceptual Outlines. The Advent of netwar. Santa Monica, CA: RAND Corporation, 1996. p.277. Disponível em:

<http://www.rand.org/pubs/monograph_reports/MR789>. Also available in print form. Acesso em 05/08/2011.

BACK, L, KEITH, M, SOLOMOS, John. Racism on the Internet: mapping neofascist subcultures in cyberspace. BJØRGO, T., KAPLAN, J. (Orgs.). Nation and race: the developing Euro-American racista subculture. Austin, TX: Northeastern University Press, 1998. p.73-101.

BARBOSA, Jefferson R. Ideologia e intolerância: a Extrema Direita latino-americana e a atuação no Brasil dos herdeiros do Eixo. Aurora, ano II, n. 2 p.2-11, jun., 2008.

BARTOLETTI, Susan C. Juventude hitlerista: a história dos meninos e meninas nazistas e a dos que resistiram. Trad. B.Horta. Rio de Janeiro: Relume Dumará, 2006.

BAUMAN, Zygmunt. Globalização: as consequências humanas. Trad. Marcus Penchel. Rio de Janeiro: Jorge Zahar Editor, 1999.

BAUMAN, Zygmunt. O amor líquido: sobre a fragilidade dos laços humanos. Trad. Carlos Alberto Medeiros. Rio de Janeiro: Jorge Zahar Editor, 2004.

BÉDARIDA, François. Tempo presente e presença da história. Usos \& abusos da história oralAMADO, Janaína, FERREIRA, Marieta de Moraes Ferreira. 7 ed. Rio de Janeiro: Editora FGV, 2005.p.219-232 
BLOCH, Marc. Apologia da história ou o ofício do historiador. Rio de Janeiro: Jorge Zahar Editor, 2001.

BLOCH, Marc. Por une Histoire Comparée des societies européennes. Revue de Synthèse Historique, n. 46, p. 15-50.

BLOCH, Marc. Reis taumaturgos - o caráter sobrenatural do poder régio: França e Inglaterra. Pref. Jacques Le Goff. Trad.Júlia Mainard. São Paulo, Cia das Letras. $2^{\text {a }}$.Reimp., 1999.

BOBBIO, Noberto. Dicionário de política. Trad. João Ferreira, Carmem varriale et al. Brasília: Editora Universidade de Brasília, 1986.

BORIN, Marta Rosa. Revionismo/Negacionismo. In: MEDERIOS, Sabrina Evangelista, SILVA, Francisco Carlos Teixeira da, VIANA, Alexander Martins. Dicionário crítico do pensamento da direita: idéias, instituições e personagens. Rio de Janeiro: FAPERJ/Mauad, 2000.p.397

BRESCIANO, Juan Andrés. I historiador y las fuentes eletrônicas: nuevos horizontes para La crítica heurística en siglo XXI. Data., Disponivel em <http;//WWW.h-debate.com/Sesión 15/05/08 Seminario "on line"> . Acesso em 12 dez. 2008.

CAMUS, Jean-Yves. Skinheads. In: MEDERIOS, Sabrina Evangelista, SILVA, Francisco Carlos Teixeira da, VIANA, Alexander Martins. Dicionário crítico do pensamento da direita: idéias, instituições e personagens. Rio de Janeiro: FAPERJ/Mauad, 2000. p.417-419

CASTELLS, Manuel. A Galáxia internet: reflexões sobre a Internet, os negócios e a sociedade. Trad. Maria Luiza X. Borges. Rio de Janeiro: Jorge Zahar Ed., 2003.

CERTEAU, Michel de. A invenção do cotidiano: artes do fazer. Trad. Ephraim Ferreira Alves. Petrópolis, RJ: Vozes, 1994.

CHAUVEAU, Agnès, Tétart, Philippe. Questões para a história do presente. Bauru, SP: EDUSC, 1999 .

COHEN, Daniel J., ROSENZWEIG, Roy. Digital history: a guide to gathering, preserving, and presenting the past on the web. Philadelphia: University of Pennsylvania Press, 2006.

COSTA, Márcia Dias. Carecas do subúrbio: caminhos de um Nomadismo Moderno.

Petrópolis: Vozes, 1993 
DETIENNE, Marcel. Comparar o incomparável. Aparecida, São Paulo, Idéias \&

DIAS, Márcia. Carecas do subúrbio: caminhos de um Nomadismo Moderno. Petrópolis: Vozes, 1993.

EUMC - Relatório Anual 2004/2005 - observatório europeu do racismo e da xenofobia. (Parte 1). Local: EUMC, data.

FEBRVE, Lucien. Face ao Vento. Manifesto dos Anais Novos (1946). In: História. São Paulo: Ática, 1992. p.173-182

FEBVRE, Lucien. História. MOTA, Carlos G.(Org.). 2 ed. SP:Ática, 1992.

GABLE, Gerry, JACKSON, Paul (Orgs). Far-Right.com: nationalist extremism on the Internet. Northamton: University of Northhampton, 2012.

GEERTZ, Clifford. Uma descrição densa: por uma teoria interpretativa da cultura. In: . A interpretação das culturas. Rio de Janeiro: LTC, 1989.p.3-24.

GINZBURG, C. O nome e o como: troca desigual e mercado historiográfico. A microhistória e outros ensaios. Trad. António Narino. Lisboa: Difel/ Rio de janeiro: Bertrand Brasil, 1989. p.169-178.

GINZBURG, C. Sinais: raízes de um paradigma indiciário. Mitos, emblemas e sinais: morfologia e história. Trad. F. Carotti. São Paulo: Cia das Letras, 2002. p.143-180.

HOBSBAWM, Eric J. Era dos extremos: o breve século XX. 2 ed. São Paulo: Companhia das Letras, 1997.

HOBSBAWM, Eric J. Nações e nacionalismo desde 1870: programa, mito e realidade. Trad. Maria C. Paoli e Anna M. Quirino. Rio de Janeiro: Paz e Terra, 1990.

KERSHAW, Ian. Hitler, the germans, and the final Solution. London/Yale University Press, 2008

KOCKA, Jürgen. Comparison and beyond. History and theory, Vol. 42, No. 1 (Feb., 2003), pp. 39-44

KOLLMANN, Raúl. Sombras de Hitler: la vida secreta de las bandas neonazis argentinas. Buenos Aires: Editorial Sudamericana: 2001 
KOSELLECK, Reinhart. Futuro passado: contribuição à semântica dos tempos históricos. Trad. Wilma Patrícia Maas, Carlos Almeida Pereira. Rio de Janeiro: Contraponto/Ed. PUCRio, 2006.

LE GOFF, Jacques. História e memória. Campinas, SP: Editora da UNICAMP, 1990.p.13-148. (Coleção Repertórios).

LÉVY, Pierre. Cibercultura. 2 ed. Rio de Janeiro: Editora 34, 2000.

Luis Alberto. Breve história contemporánea de la Argentina (1916-2010). 3. ed. Buenos Aires: Fondo de Cultura Económica, 2012.

MAYNARD, Dilton (Org.) História, neofascismos e intolerância: reflexões sobre o tempo presente. São Cristóvão/rio de Janeiro: Edufs/Luminárias, 2012.

MAYNARD, Dilton C.S. A intolerância on line: aspectos da propaganda da extrema-direita brasileira na Internet. In: SIMPÓSIO NACIONAL DE HISTÓRIA, XXII, Florianópolis, 2005. Anais eletrônico... Florianópolis: Editor, 2005. Um CD-ROM.

MAYNARD, Dilton C.S. Intolerância em rede: apropriações da internet pela extremadireita (1999-2009). Revista Eletrônica Boletim do Tempo, Ano 5, n.10, p.00-00, 2010.

MAYNARD, Dilton. Escritos sobre história e internet. Rio de Janeiro: FAPITEC/Luminárias, 2011.

MEDERIOS, S. E., VALENTE, L. O Manifesto de Anders Breivik. Um atentado anunciado: Noruega, 22 de julho de 2011. Revista Estudos Políticos. n. 3, p.00-00, jul./dez. 2011

MILMAN, Luis, VIZENTINI, Paulo Fagundes. Neonazismo, negacionismo e extremismo político. Porto Alegre: Ed.UFRGS, 2000.

MOYANO, A. L. Neonazis: la seducción de la svástica. Nowtilus: Madrid, 2004..

NEUMANN, Franz. Behemoth: the structure and practice of national socialism, 1933-1944. Chicago: Ivan R. Dee/United States Memorial Museum, 2009

NORA, Pierre. Entre memória e história: a problemática dos lugares. Trad. Yara Aun Khoury. Projeto História. São Paulo, 1981.p.7-28.p.12-13

NORA, Pierre. O retorno do fato. LE GOFF, J. NORA, P. História: novos problemas. Rio de janeiro: Livraria Francisco Alves, 1976.p.179-193. 
PAXTON, Robert. A anatomia do fascismo. Trad. Patrícia Zimbres e Paula Zimbres. Rio de Janeiro: Paz \& Terra, 2007.

PRADO, Maria Ligia Coelho. Repensando a história comparada da América Latina. Revista de História. Universidade de São Paulo, n. 153, p.11-33, 2005,

PROST, Antoine. Doze lições sobre história. Tradução Guilherme João de Freitas Texeira. Belo Horizonte: Autêntica Editora, 2009.

PURDY, Sean. A História Comparada e o Desafio de Transnacionalidade. Revista de História Comparada. p.1. V.6 - N. 1 - Julho/2012. <www.hcomparada.historia.ufrj.br/revistahc/artigos/volume006_Num001_artigo003.pdf> acesso em 23/12/2012.

QUITTNER, Joshua, STAMPER, Chris. Home pages for hate. Time. Jan. 22, 1996. Disponível em: www.time.com/time/.../0,9171,983994,00.html . Acesso em20/08/2011.

RIDGEWAY, James. Blood in the face: the Ku, Klux, Klan, Aryan Nations, Nazi skinheads, and the Rise of a New White Culture. 2 ed. New York: Thunder's Mother Press, 1995.

ROSENZWEIG, Roy. Scarcity or Abundance? preserving the past. In: Clio wired: the future on the past in the digital age. New York: Columbia University Press, 2011.

SALAS, Antonio. Diário de um skinhead: um infiltrado no movimento neonazista. Trad. Magda Lopes. São Paulo: Planeta, 2006.

SEIGNOBOS, Charles. História comparada dos povos da Europa. 2 ed. Rio de Janeiro: José Olympio, 1945.

SERKAN, Gül. Method and practice in comparative history. Karadeniz Araştırmaları, ano 2010, n.26, p. 143-158, 2010. Disponível em: <

http://www.karam.org.tr/Makaleler/91886581_gul.pdf> Acesso em 12/12/2012.

SILVA, Francisco Carlos T. Um estrondo na Noruega: quando o diabo bate à porta [1]. Carta Maior. 25/07/2011. Disponível em

$<$ http://www.cartamaior.com.br/templates/colunaMostrar.cfm?coluna_id=5134>. Acesso em

SILVA, Francisco Carlos Teixeira da, VIANA, Alexander Martins. Dicionário crítico do pensamento da direita: idéias, instituições e personagens. Rio de Janeiro: FAPERJ/Mauad, 2000. 
SILVA, Francisco Carlos Teixeira da. O retorno: é primavera em Zwickau, Alemanha. Carta Maior. 24/01/2012. Disponível em

<http://www.cartamaior.com.br/templates/colunaMostrar.cfm?coluna_id=5423>. Aacesso em: .

SILVA, Francisco Carlos Teixeira da. Neofascismo. Revista Eletrônica Boletim do Tempo Presente, v.00, n.00, data. Disponívlel em:

http://www.tempopresente.org/index.php?option=com_content\&task=view\&id=34\&ltem id=124. Acesso em 29/03/2008.

SILVA, Francisco Carlos Teixeira da. O debate do Holocausto como paradigma da intolerância. Revista Eletrônica Carta Maior, v.00, n.00, p.00-00, data. Disponível em< www.cartamaior.com.br> acesso em 28/03/2008; disponível também via http://www.tempopresente.org/index.php?option=com_content\&task=view\&id=1467\&lt emid $=124$. Accesso em 29/03/2008.

SILVA, Francisco Carlos Teixeira da. O século XX: entre luzes e sombras. In: O século sombrio: uma história geral do século XX. Rio de Janeiro: Elsevier, 2004.p.1-25.

THEML, Neyde; BUSTAMANTE, Regina. História Comparada: Olhares Plurais. Revista de História Comparada. v.1, n.1, p.00-00, Junho 2007. 
Recebido em 31/03/2014 Aprovado em 01/08/2014

Universidade do Estado de Santa Catarina - UDESC

Programa de Pós-Graduação em História - PPGH

Revista Tempo e Argumento

Volume 06 - Número 12 - Ano 2014

tempoeargumento@gmail.com 